\title{
Antimicrobial Activities of Endophytic Fungal Crude Extracts Isolated from Cashew Tree (Anacardium occidentale)
}

\author{
Nana Amiri and Donatha D Tibuhwa \\ Department of Molecular Biology and Biotechnology, University of Dar es Salaam, P. O. Box \\ 35179, Dar es Salaam, Tanzania. \\ Corresponding author, e-mail: nanaamiri91@gmail.com \\ Received 14 Aug 2020, Revised 6 Jul 2021, Accepted 20 Jul 2021, Published Aug 2021
}

DOI: https://dx.doi.org/10.4314/tjs.v47i3.20

\begin{abstract}
This study presents the antimicrobial activities of endophytic fungal crude extracts isolated from leaves, stems and roots of cashew trees (Anacardium occidentale) which showed disease symptoms and those resistant from Fusarium wilt in Mtwara region. Sections of the cashew trees were made and cultured to isolate endophytes. Eight endophytes were isolated and characterized by using morphological and molecular markers. Neopestalotiopsis, Penicillium, Lasidioplodia and Daldinia sp isolated from resistant tree and Auxarthron and Aspergillus sp from diseased tree. Antimicrobial activities of the isolated endophytic fungal crude extracts were done against pathogenic Fusarium oxysporum and three human pathogens namely, Staphylococcus aureus, Escherichia coli, and Candida tropicalis. Results showed that all endophytic fungal crude extracts isolated from resistant plants and one from diseased plants exhibited positive antimicrobial activities against bacteria and fungus Candida tropicalis but they had no antifungal activity against Fusarium oxysporum. This study could contribute to the discovery and innovation of therapeutics. This study also implied that the resistance against Fusarium wilt disease might be caused by other unknown factors. More research work is recommended for establishing other possible factors including endophytic bacteria, biotic and abiotic factors that could contribute to resistance of cashew plants to Fusarium oxysporum.
\end{abstract}

Keywords: Antifungal, Phytopathology, Endophyte and Cashew nut disease.

\section{Introduction}

Endophyte refers to a bacterium or fungus that lives within the plant's parts such as stem, roots, leaves and branches and exhibits no harm to that particular plant. Endophytes have been studied in most plants and found to live asymptomatically (Schulz et al. 1993). It has been observed that, they have capacity to affect the physiology, ecology and distribution of the host plants (Sridhar and Raviraja 1995). They can influence the host plant to resist diseases, nematodes, insects and other stresses. Endophytes are also known to produce natural bioactive compounds which are mainly applied in agriculture, food industry and medicine (Verma et al. 2009).

The occurrence of the unknown cashew wilt diseases in Mtwara region, Tanzania, which is among the cashew grower's regions, has brought up another challenge to most growers. The unknown infections resulted in low yields thus increasing poverty and general frustrations which forced them to abandon the crop. That wilting disease widespread within few weeks of its occurrence which led to complete loss of cashew trees at the field. Laboratory analyses and pathogenicity test revealed the pathogen-causing cashew wilting 
disease to be Fusarium oxysporum (Mbasa et al. 2020, Tibuhwa and Shomari 2016). Recently, it has been observed that there are some cashew trees that do not wilt at all although they grow in the vicinity of wilting ones. This triggered an interest to investigate the possibility of the presence of endophytes that might be promoting their growth and prevent them from pathogen's attacks. The present study aimed at establishing the possibility of the presence of endophytes that might be enhancing immunity in cashew trees and protecting them from Fusarium wilt.

\section{Materials and Methods}

\section{Sample collection}

Samples were collected from Mtwara region in Tandahimba District and Newala District in August 2019. Purposive random sampling was used to choose disease and resistant cashew trees and from those trees, simple random sampling was used. Three symptomatic (diseased) cashew trees per site and three asymptomatic (resistant) cashew trees were selected within the infested cashew fields. Five leaves samples were collected from each diseased and resistant tree, making a total of 30 leaves samples. The same method was applied in collecting stems and roots samples, also resulting in 30 samples. The samples were collected using knife and hand hoe, kept in plastic bags and then transported to the Department of Molecular Biology and Biotechnology laboratories of the University of Dar es Salaam for further analysis.

\section{Isolation of endophytic fungi}

Leaves, stems and roots from the collected samples were cleaned under tap running water for $30 \mathrm{~min}$ and cut into $1 \mathrm{~cm}$ segments. Surface sterilizations were done using $70 \%$ ethanol for 2 min followed by sodium hypochlorite solution (2\% available chlorine) for $3 \mathrm{~min}$ and $70 \%$ ethanol for $30 \mathrm{~s}$ followed by three washes in sterile distilled water. Leaf, stem and root segments of about $2 \mathrm{~cm}$ each were placed on Petri plates containing Potato Dextrose Agar (PDA) medium amended with streptomycin
$(250 \mathrm{mg} / \mathrm{l})$ to slow down bacterial growth from the tissue (Schulz et al. 1993). PDA plates with samples and controls (without samples) were incubated at $30{ }^{\circ} \mathrm{C}$ for 5-6 days. Fungi that grew out from the plant tissues were transferred onto fresh PDA medium. After purifying the isolates three times, final pure cultures were transferred into PDA slants in test tubes and stored at $4{ }^{\circ} \mathrm{C}$ for further examinations.

\section{Morphological characterization}

Macro morphological and micro-morphological characterizations were used to characterize the pure culture isolates. From a pure culture colony, various parameters such as mycelia types, colony appearance and colony colour were determined. Staining of the colony were done with lactophenol cotton blue stain and microscopic features were studied under a compound microscope (Leica 2500, Leica Microsystems CMS GmbH, and Wetzler, Germany). The observed fungi were identified to the genus level using standard identification keys as reported by Masumi et al. (2015). Further characterization for ascertaining the identified isolated were done using molecular markers.

\section{Molecular characterization}

Genomic DNA was extracted by CTAB extraction method as described by Umesha et al. (2016), with some modification. Briefly, $100 \mathrm{mg}$ of fungi isolates were placed in eppendorf tube followed by addition of glass beads, $200 \mu \mathrm{L} \mathrm{CTAB}$ and grinding. CTAB $(300 \mu \mathrm{L})$ was added followed by incubation in water bath at $65{ }^{\circ} \mathrm{C}$ for $45 \mathrm{~min}$ followed by centrifugation for $5 \mathrm{~min}$ at $8000 \mathrm{rpm}$. $400 \mu \mathrm{L}$ of the aqueous phase obtained were placed in a new collection tubes then $500 \mu \mathrm{L}$ of chloroform: isoamyl alcohol (24:1) were added, mixed gently followed by centrifugation for $5 \mathrm{~min}$ at $8000 \mathrm{rpm}$. In the aqueous phase, $500 \mu \mathrm{L}$ of isopropanol were added, mixed gently followed by incubation at $-20{ }^{\circ} \mathrm{C}$ for 1 hour to precipitate DNA. Following incubation, the solution was centrifuged for $10 \mathrm{~min}$ at $14000 \mathrm{rpm}$ and supernatant discarded. 
Amiri and Tibuhwa - Antimicrobial Activities of Endophytic Fungal Crude Extracts ...

Subsequently, $100 \mu \mathrm{L}$ of $70 \%$ ethanol were added to wash the DNA, vortex and allowed to dry for $30 \mathrm{~min}$. The DNAs obtained were stored in $30 \mu \mathrm{L}$ of DNAse free water for further analysis. DNA concentrations were determined using the Nanodrop spectrophotometer (Thermo Scientific Nanodrop 2000) at absorbance of 260/280 nm.

PCR amplification of the fungal rDNA internal transcribed spacers (ITS) regions of all the isolates were done using the primer pairs ITS1 and ITS4. PCR amplifications conditions included 1 cycle of $94^{\circ} \mathrm{C}$ for $3 \mathrm{~min}$, followed by 35 cycles of $94{ }^{\circ} \mathrm{C}$ for $30 \mathrm{sec}, 55^{\circ} \mathrm{C}$ for 1 min, and $72{ }^{\circ} \mathrm{C}$ for $1 \mathrm{~min}$ and a final extension cycle of $72{ }^{\circ} \mathrm{C}$ for $10 \mathrm{~min}$ (Ramesh et al. 2017). The PCR products were checked for quality using gel electrophoresis. The PCR products were then directly sequenced at INQABA South Africa. The nucleotide sequences attained from INQABA were checked first for quality control, and analyzed using Basic Alignment Search Tool (BLAST) against the GenBank sequence database available in the National Center for Biotechnology Information (NCBI) website at: http://blast.ncbi.nlm.nih.gov (Ronoh et al. 2013)

\section{Phylogenetic analysis}

The obtained nucleotide sequences were deposited in public database the GenBank and were assigned the following accession numbers: SUB9369567 seq1 MW840081, SUB9369567 seq2 MW840082, SUB9369567 seq3 MW840083, SUB9369567 seq4 MW840084, SUB9369567 seq5 MW840085, SUB9369567 seq6 MW840086, SUB9369567 seq7 MW840087 and SUB9369567 seq8 MW840088.

The sequences were further aligned using the CLUSTAL W program against the nearest neighbours. The phylogenetic analyses were done using Maximum likelihood and Bayesian analysis while the optimal substitution model for ITS was designated using Akaike's Information Criterion (AIC) with MrModeltest 2.3 (Nylander 2004). Phylogenetic analysis was performed in a Bayesian Inference conducted using MrBayes v3.2.6 (Ronquist and Huelsenbeck 2003). Two independent runs of four Monte Carlo Markov Chains (MCMC) were performed; a run length of 10,000,000 generations sampled every 1,000th, and a GTR+I substitution model. A burn-in of $25 \%$ was removed from each run. Maximum likelihood estimates were carried out by RAxML v.8.2.10 using the GTR + G + I model of site substitution (Stamatakis 2014). The branch support was obtained by maximum likelihood bootstrapping (MLbs) of 1000 replicates (Hillis and Bull 1993). The evolutionary history was inferred using the Maximum likelihood method. The bootstrap consensus trees inferred from 1000 replicates were taken to represent the evolutionary history of the taxa analyzed. The evolutionary distances were computed using the Maximum Composite Likelihood method (Ronoh et al. 2013).

\section{Isolation of endophytic fungi for antimicrobial activities}

Endophytic fungal metabolites were screened for antimicrobial activities. By using sterile cork borer, mycelial agar from each endophyte was cut from the edge of an actively grown pure culture and inoculated into a $500 \mathrm{~mL}$ conical flask containing $250 \mathrm{~mL}$ of sterile potato dextrose broth media by using sterilized spatula and then followed by incubation at room temperature for three weeks without shaking as described by Campos et al. (2015).

\section{Extraction of metabolites of the endophytic fungi}

After three weeks incubations, cultures of endophytic fungi were filtered using cotton gauze to remove mycelial mats. Fungal metabolites were extracted by solvent extraction procedures using ethyl acetate as organic solvent (Mwanga et al. 2019). Equal volumes of metabolites filtrate and ethyl acetate were measured and placed into separating funnel; the mixture was shaken vigorously for $10 \mathrm{~min}$ and then left to stand to 
allow cell masses to get separated from the solution. The aqueous solution was discarded and the organic solution was collected and kept in a sterilized flask (with known mass) and metabolites were extracted by removing excess solvent using rotary vacuum evaporator (BUCHI Rota vapor Model R-210) under reduced pressure at $35{ }^{\circ} \mathrm{C}$. The fungal crude extracts obtained were weighed, dissolved in dimethyl sulfoxide (DMSO) and stored at $4{ }^{\circ} \mathrm{C}$ for antimicrobial assays.

\section{Inoculum preparation}

Gram-positive bacteria, Staphylococcus aureus (ATCC-25923), gram negative bacteria Escherichia coli (ATCC-25922) and a yeast Candida tropicalis used were obtained from the Department of Molecular Biology and Biotechnology, University of Dar es Salaam. The bacteria and yeast were grown in nutrient agar (NA) and potato dextrose agar (PDA) and incubated at $37{ }^{\circ} \mathrm{C}$ and $30{ }^{\circ} \mathrm{C}$, respectively for 24 hours. By using sterile inoculating loop, cultures of test organisms were placed into sterile test tubes each containing $1 \mathrm{~mL}$ of sterile saline water, and the suspension was adjusted to match with 0.5 McFarland standards approximately $1.5 \times 10^{8} \mathrm{CFU} / \mathrm{mL}$ (prepared by adding $0.05 \mathrm{~mL}$ of $1.175 \% \mathrm{BaCl}_{2}$ to $9.95 \mathrm{~mL}$ of $1 \% \mathrm{H}_{2} \mathrm{SO}_{4}$ ). The suspensions of tested organisms and saline water were then kept in the test tubes and stored at $4{ }^{\circ} \mathrm{C}$ until used following the procedure described by Jahiri (2013) and Mwanga et al. (2019).

\section{Screening for antimicrobial activity}

Only eight (8) crude extracts of the isolated and ascertained endophytic fungi were screened for their antibacterial and antifungal activities against the Escherichia coli, Staphylococcus aureus, Fusarium oxysporum and Candida tropicalis. About $20 \mu \mathrm{L} /$ disc solvent extract with concentrations of 200 $\mathrm{mg} / \mathrm{mL}$ were soaked to each sterile Whatman disc with a diameter of $6 \mathrm{~mm}$ and allowed to dry and then placed on the inoculated media. Mueller-Hinton sterile agar plates were seeded with indicator bacterial strains $\left(10^{8} \mathrm{CFU}\right)$, while Sabouraud dextrose agar media were seeded with indicator fungus. Control experiments were carried out under similar conditions by using chloromphenical for antibacterial activities and fluconazole for antifungal activities (positive control) as standard drugs while dimethyl sulfoxide (DMSO) was used as a negative control. The zones of growth inhibition around the disks were measured after 18 to 24 hours of incubation at $37{ }^{\circ} \mathrm{C}$ for bacteria and 48 to 96 hours for fungi at $28{ }^{\circ} \mathrm{C}$. The sensitivities of the microorganisms to the fungal extracts were determined by measuring the sizes of inhibitory zones in millimeters (including the diameters of disks) on the agar surface around the disks, and those showing no zones were termed as negative (Bhalodia and Shukla 2011). The treatments were performed in triplicates and the results presented as mean value $( \pm$ standard deviation). The fungal crude extracts that showed high zones of inhibition against the test microorganisms were tested for Minimum Inhibitory Concentrations (MIC).

\section{Minimum inhibitory concentrations}

Determination of minimum inhibitory concentrations of fungal crude extracts which showed higher zones of inhibition against test organisms were performed using the 96-well microtiter plate with lid, having 12 columns and 8 rows $(\mathrm{A}-\mathrm{H})$. The fungal extracts and the standard drugs were prepared in a concentrations that were twice the desired final concentration $(200 \mu \mathrm{L})$ as were diluted with an equal amount of bacteria in broth. Two fold serial dilutions using a micropipette were done systematically down the columns $1-9.100 \mu \mathrm{L}$ was removed from the starting concentrations (columns 1-9 in row A) and transferred to the next row with the $100 \mu \mathrm{L}$ broth, properly mixed, and the procedure was repeated up to the last row $(\mathrm{H})$ where the last $100 \mu \mathrm{L}$ was discarded. This brought the final volume in all the test wells with the extracts and the standard drugs to $100 \mu \mathrm{L}$, except the $10^{\text {th }}$ column which had $200 \mu \mathrm{L}$ of the broth that served as growth control (drug free). Each fungal extract was set 
with its blank which contained fungal extracts and broth without microorganisms. Columns 11 and 12 served as positive control and negative control, respectively. Microtiter plates were incubated at $37^{\circ} \mathrm{C}$ and the MIC values were determined by Spectrostar analyser (Dharajiya et al. 2017).

\section{Results}

Macro-morphological characterization and sequencing

In this study, twenty three (23) endophytic fungi were successfully isolated from healthy and diseased plants. Both macro-morphological and micro-morphological characterizations were carried out which categorized the isolated endophytes into six genera corresponding to Neopestalotiopsis, Penicillium, Daldinia, Auxarthron, Aspergillus and Lasidioplodia. However, morphological characters failed to delineate them to species level, hence

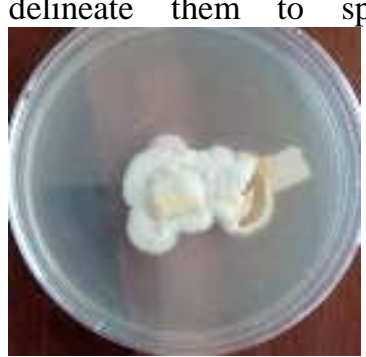

(a)

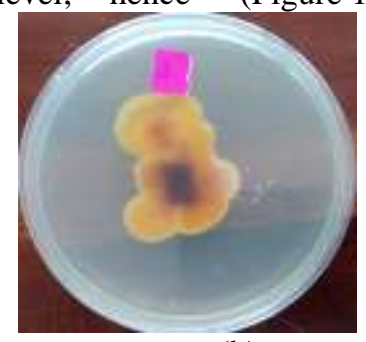

(b) molecular based techniques were deployed for further delimitations. Out of the 23 isolated endophytes, DNA extraction, amplification and purification for sequencing were successfully done to only thirteen (13) endophytes. Out of the 13 sequenced, only eight (8) were clean sequences for phylogenetic analysis, thus clearly ascertained their identity. The eight clean sequences were from health leaves (3), diseased roots (2), while the resistant roots and diseased stems each had one (1) clean sequence.

\section{Neopestalotiopsis sp}

After 7 days of incubation, at the upper side of the medium, white colonies, cottony like, circular in shape were observed, while at the reverse side of the medium, light-yellow colouration portrayed (Figure 1a \& b). Conidia were fusiform to ellipsoid under microscope (Figure 1c).

Figure 1: Neopestalotiopsis sp isolated from (a) healthy leaves (b) reverse side (c) conidia (arrows) observed under light microscope with 40X magnification.

\section{Penicillium sp}

After 7 days of incubation, colonies grew rapidly, and were predominantly pale green with a greenish white margin at the upper side of the medium, while the reverse side of the medium was pale yellow (Figure $2 \mathrm{a} \& 2 \mathrm{~b}$ ). Conidia were spherical and closely packed under light microscope (Figure c).

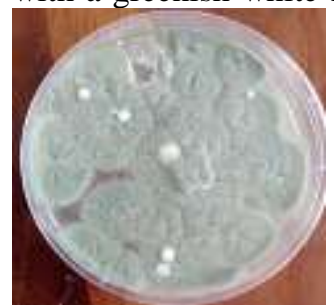

(a)

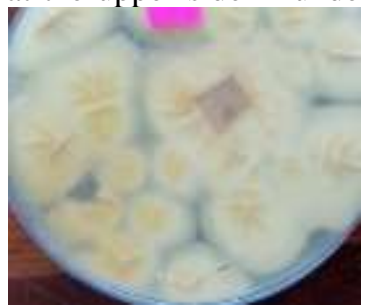

(b)

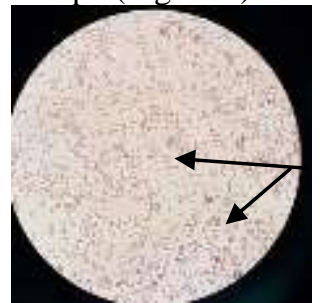

(c)

Figure 2: Penicillium sp isolated from (a) healthy leaves (b) reverse side (c) conidia (arrows). observed under light microscope with 40X magnification. 


\section{Aspergillus sp}

After 7 days of incubation, white colonies appeared first then becoming black with the production of conidiophore (Figure $3 a$ and $b$ ). Initially conidial heads were radiate and at maturity they split into two columns. Under microscope, the conidiophores were long, radiate, smooth and hyaline, becoming darker at the apex, and terminate in a globose vesicle (Figure 3c).

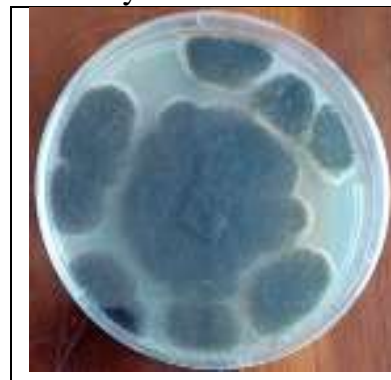

(a)

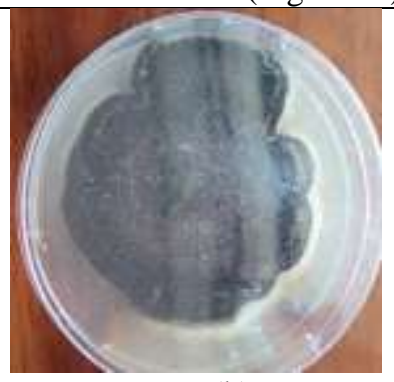

(b)

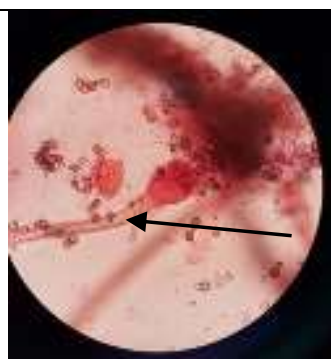

(c)

Figure 3: Aspergillus sp isolated from (a) diseased leaf (b) diseased root (c) conidiophore (arrow) observed under light microscope with 40X magnification

Molecular characterization of endophytic fungi

Molecular characterization of identified endophytic fungi isolated from leaves, stems and roots of cashew trees were done using rDNA sequences. The internal transcribed spacer (ITS) sequences of the specimen were compared with sequences in the GenBank, using Blast to determine identity levels. Analysis showed that all the sequences of the endophytic fungi were greater than $90 \%$ and were similar when compared with the sequences from the database, and hence confirmed them to belong to the genera Neopestalotiopsis, Penicillium, Daldinia, Lasidioplodia, Auxarthron, Aspergillus, and Lasidioplodia with the percentage identities of $100 \%, 99.61 \%, 100 \%, 100 \%, 99.45 \%, 100 \%$, $99.81 \%$ and $100 \%$, respectively (Table 1 ).

Table 1: Identified fungi and the percentage identity of isolated endophytic fungi from different parts of cashew trees and that of the taxa found in the NCBI.

\begin{tabular}{|c|c|c|c|c|}
\hline $\begin{array}{l}\text { Code } \\
\text { number }\end{array}$ & Name of species & $\begin{array}{l}\text { Accession } \\
\text { number }\end{array}$ & $\begin{array}{l}\text { Maximum \% } \\
\text { identity }\end{array}$ & References \\
\hline $\begin{array}{l}\text { Isolate } \\
3(\mathrm{C})\end{array}$ & $\begin{array}{l}\text { Neopestalotiopsis } \\
\text { mesopotamica } \\
\text { Neopestalotiopsis } \\
\text { javaensis } \\
\text { Neopestalotiopsis } \\
\text { acrostichi } \\
\text { Neopestalotiopsis } \\
\text { surinamensis } \\
\text { Neopestalotiopsis } \\
\text { javaensis } \\
\text { Neopestalotiopsis } \\
\text { australis } \\
\text { Neopestalotiopsis rosae }\end{array}$ & $\begin{array}{l}\text { NR_145244 } \\
\text { MH855207 } \\
\text { MK764272 } \\
\text { NR_145240 } \\
\text { NR_145241 } \\
\text { KM199348 } \\
\text { NR_145243 }\end{array}$ & $\begin{array}{l}100 \\
100 \\
100 \\
100 \\
100 \\
100 \\
100\end{array}$ & $\begin{array}{l}\text { Maharachchikumbura et al } \\
\text { (2014) } \\
\text { Vu et al. (2019) } \\
\text { Norphanphoun et al. (2019) } \\
\text { Maharachchikumbura et al. } \\
\text { (2014) } \\
\text { Maharachchikumbura et al. } \\
\text { (2014) } \\
\text { Norphanphoun et al. (2019) } \\
\text { Maharachchikumbura et al } \\
\text { (2014) }\end{array}$ \\
\hline $\begin{array}{l}\text { Isolate } \\
\text { 4(D) }\end{array}$ & $\begin{array}{l}\text { Penicillium wotroi } \\
\text { Penicillium }\end{array}$ & NR_119813 & 99.61 & Schoch et al. (2014) \\
\hline
\end{tabular}


Amiri and Tibuhwa - Antimicrobial Activities of Endophytic Fungal Crude Extracts ...

\begin{tabular}{|c|c|c|c|c|}
\hline $\begin{array}{l}\text { Code } \\
\text { number }\end{array}$ & Name of species & $\begin{array}{l}\text { Accession } \\
\text { number }\end{array}$ & $\begin{array}{l}\text { Maximum \% } \\
\text { identity }\end{array}$ & References \\
\hline & $\begin{array}{l}\text { pedernalence } \\
\text { Penicillium } \\
\text { infrabuccalum }\end{array}$ & $\begin{array}{l}\text { NR_146250 } \\
\text { KT887849 }\end{array}$ & $\begin{array}{l}98.88 \\
98.86\end{array}$ & $\begin{array}{l}\text { Laich and Andrade (2016) } \\
\text { Visagie et al. (2016) }\end{array}$ \\
\hline $\begin{array}{l}\text { Isolate } 6 \\
\text { (F) }\end{array}$ & $\begin{array}{l}\text { Lasidioplodia iranensis } \\
\text { Lasidioplodia sterculiae } \\
\text { Lasidioplodia } \\
\text { jastrophicola } \\
\text { Lasidioplodia chinensis } \\
\text { Lasidioplodia hyalina } \\
\text { Lasidioplodia } \\
\text { pseudotheobromae }\end{array}$ & $\begin{array}{l}\text { NR_147327 } \\
\text { NR_147365 } \\
\text { NR_147348 } \\
\text { NR_152983 } \\
\text { NR_152982 } \\
\text { NR_111264 }\end{array}$ & $\begin{array}{l}100 \\
100 \\
100 \\
100 \\
100 \\
100\end{array}$ & $\begin{array}{l}\text { Abdollahzadeh et al. (2010) } \\
\text { Yang et al. (2017) } \\
\text { Machado et al. (2014) } \\
\text { Dou et al. (2017) } \\
\text { Dou et al. (2017) } \\
\text { Schoch et al. (2014) }\end{array}$ \\
\hline $\begin{array}{l}\text { Isolate } \\
7(\mathrm{G})\end{array}$ & $\begin{array}{l}\text { Daldinia starbaeckii } \\
\text { Daldinia bambusicola } \\
\text { Daldinia bambusicola }\end{array}$ & $\begin{array}{l}\text { NR_147519 } \\
\text { KU683755 } \\
\text { NR_152464 }\end{array}$ & $\begin{array}{l}100 \\
100 \\
100\end{array}$ & $\begin{array}{l}\text { Stadler et al. (2014) } \\
\text { U'Ren et al. (2016) } \\
\text { U'Ren et al. (2016) }\end{array}$ \\
\hline $\begin{array}{l}\text { Isolate } \\
9(\mathrm{H})\end{array}$ & $\begin{array}{l}\text { Auxarnthron } \\
\text { conjugatum } \\
\text { Auxarnthron } \\
\text { conjugatum } \\
\text { Auxarnthron zuffianum } \\
\text { Auxarnthron } \\
\text { compactum } \\
\text { Auxarthron alboluteum }\end{array}$ & $\begin{array}{l}\text { NR_121475 } \\
\text { MH857772 } \\
\text { MH869293 } \\
\text { NR_103574 } \\
\text { NR_111137 }\end{array}$ & $\begin{array}{l}99.44 \\
99.45 \\
91.44 \\
91.17 \\
90.25 \\
\end{array}$ & $\begin{array}{l}\text { Schoch et al. (2014) } \\
\text { Vu et al. (2019) } \\
\text { Vu et al. (2019) } \\
\text { Schoch et al. (2014) } \\
\text { Schoch et al. (2014) }\end{array}$ \\
\hline $\begin{array}{l}\text { Isolate } \\
10(\mathrm{I})\end{array}$ & $\begin{array}{l}\text { Aspergillus tubingensis } \\
\text { Aspergillus tubingensis } \\
\text { Aspergillus piperis } \\
\text { Aspergillus } \\
\text { costaricaensis } \\
\end{array}$ & $\begin{array}{l}\text { EF661193 } \\
\text { NR_131293 } \\
\text { NR_077191 } \\
\text { NR_103604 }\end{array}$ & $\begin{array}{l}100 \\
100 \\
100 \\
100\end{array}$ & $\begin{array}{l}\text { Peterson (2008) } \\
\text { Peterson (2008) } \\
\text { Schoch et al. (2014) } \\
\text { Schoch et al. (2014) }\end{array}$ \\
\hline $\begin{array}{l}\text { Isolate } \\
11(\mathrm{~J})\end{array}$ & $\begin{array}{l}\text { Aspergillus aculeatus } \\
\text { Aspergillus uvarum } \\
\text { Aspergillus japonicus }\end{array}$ & $\begin{array}{c}\text { NR_111412 } \\
\text { NR_135330 } \\
\text { NR_131268 }\end{array}$ & $\begin{array}{l}99.81 \\
100 \\
100\end{array}$ & $\begin{array}{l}\text { Schoch et al. (2014) } \\
\text { Perrone et al. (2008) } \\
\text { Parenicova et al. (2015) }\end{array}$ \\
\hline $\begin{array}{l}\text { Isolate } \\
13(\mathrm{~L})\end{array}$ & $\begin{array}{l}\text { Lasidioplodia parva } \\
\text { Diplodia cajani } \\
\text { Lasidioplodia } \\
\text { brasiliensis } \\
\text { Lasidioplodia parva } \\
\text { Diplodia cajani } \\
\text { Lasidioplodia } \\
\text { marypalmiae }\end{array}$ & $\begin{array}{l}\text { MH861166 } \\
\text { NR_163672 } \\
\text { NR_147338 } \\
\text { NR_111265 } \\
\text { MH856592 } \\
\text { MH856592 }\end{array}$ & $\begin{array}{l}100 \\
100 \\
100 \\
100 \\
100 \\
100\end{array}$ & $\begin{array}{l}\text { Vu et al. (2019) } \\
\text { Vu et al. (2019) } \\
\text { Marques et al. (2013) } \\
\text { Schoch et al. (2014) } \\
\text { Vu et al. (2019) } \\
\text { Vu et al. (2019) }\end{array}$ \\
\hline
\end{tabular}




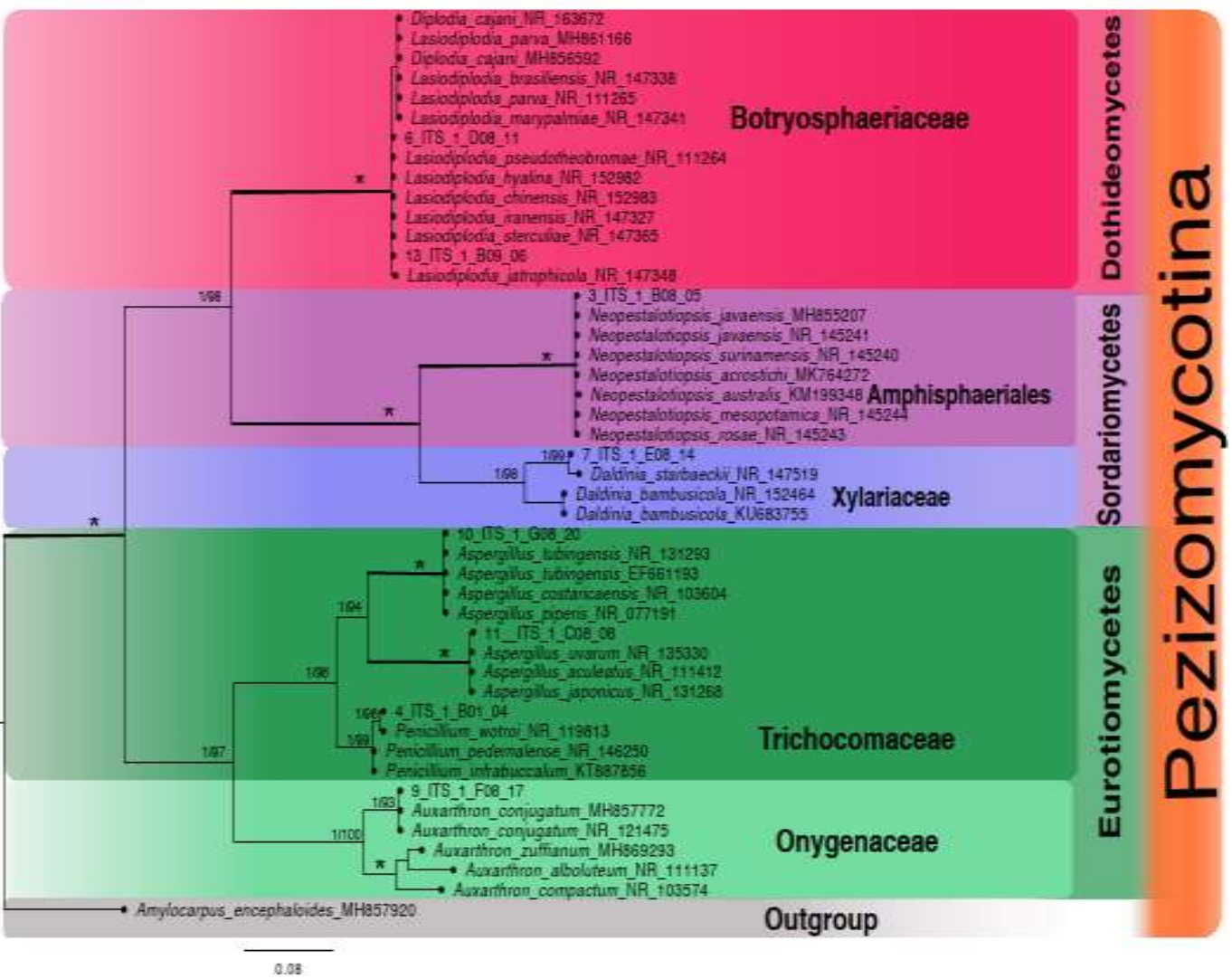

Figure 4 : Phylogenetic relationships of isolates from cashew trees based on Bayesian and ML analyses of rDNA ITS datasets. The tree was rooted with Amylocarpus encephaloides. The two support values associated with each internal branch correspond to PPs and MLbs proportions, respectively. Branches in bold indicate a support of PP $\geq 0.95$ and MLbs $\geq 70 \%$. An asterisk on a bold branch indicates that this node has a support of PP $=1.0$ and MLbs $=100$.

\section{Antimicrobial activities of fungal crude extracts}

The results were analysed by using the protocol of Quinto and Santos (2005) whereby the activities are presented as $>19 \mathrm{~mm}$ ZOI (very active), 14-19 mm ZOI (active), 10-13 mm ZOI (partially active), and $<10 \mathrm{~mm}$ ZOI (inactive). They showed that the endophytic fungal crude extracts isolated from resistant cashew trees exhibited antimicrobial activities with inhibition zones ranging from 9 to $13 \mathrm{~mm}$ against $S$. aureus, $13-23 \mathrm{~mm}$ against $E$. coli and 6 to $10 \mathrm{~mm}$ against $C$. tropicalis but had no activity against F.oxysporum (Table 2). Only one fungal species isolated from diseased cashew tree exhibited antimicrobial activities against the tested microorganisms ( $S$. aureus, E. coli and C. tropicalis) but had no activity on F.oxysporum. 
Amiri and Tibuhwa - Antimicrobial Activities of Endophytic Fungal Crude Extracts ...

Table 2: Antimicrobial activities of the crude extracts of endophytic fungi isolated from resistant and diseased cashew trees against Fusarium oxysporum and pathogens of medical importance

\begin{tabular}{llllll}
\hline Source & Endophytic fungi & \multicolumn{3}{l}{ Inhibition zone $(\mathrm{mm})$ concentration $20 \mu \mathrm{L} / \mathrm{disc}$} \\
\cline { 3 - 6 } & & $\begin{array}{l}\text { Fusarium } \\
\text { oxysporum }\end{array}$ & $\begin{array}{l}\text { Staphylococcus } \\
\text { aureus }\end{array}$ & $\begin{array}{l}\text { Escherichi } \\
\text { a coli }\end{array}$ & $\begin{array}{l}\text { Candida } \\
\text { tropicalis }\end{array}$ \\
\hline $\mathrm{R}_{1}$ Leaves $(\mathrm{n}=5)$ & Neopestalotiopsis & - & $13.0 \pm 0.47$ & $23.3 \pm 0.47$ & $10.7 \pm 0.47$ \\
$\mathrm{R}_{2}$ Leaves $(\mathrm{n}=5)$ & Penicillium & - & $12.0 \pm 0.47$ & $20.3 \pm 0.47$ & $6.67 \pm 0$ \\
$\mathrm{R}_{1}$ Roots $(\mathrm{n}=5)$ & Lasidioplodia & - & $10.0 \pm 0.47$ & $17.0 \pm 0.47$ & $9.67 \pm 0.47$ \\
$\mathrm{R}_{3}$ Leaves $(\mathrm{n}=5)$ & Daldinia & - & $9.0 \pm 0$ & $13.0 \pm 0$ & - \\
$\mathrm{D}_{1}$ Roots $(\mathrm{n}=5)$ & Aspergillus & - & - & - & - \\
$\mathrm{D}_{2}$ Roots $(\mathrm{n}=5)$ & Auxarthron & - & - & - & - \\
$\mathrm{D}_{1}$ Leaves $(\mathrm{n}=5)$ & Aspergillus & - & $12.3 \pm 0.47$ & $20.3 \pm 0.47$ & $8.3 \pm 0.47$ \\
$\mathrm{D}_{1}$ Stems $(\mathrm{n}=5)$ & Lasidioplodia & - & - & - & - \\
& +ve & - & $18.3 \pm 0.47$ & 25.3 & 10.3 \\
$\mathrm{C}$ & - ve & - & - & - & - \\
\hline
\end{tabular}

Note $\mathrm{R}_{1}=$ Resistant tree $1, \mathrm{R}_{2}=$ Resistant tree $2, \mathrm{R}_{3}=$ Resistant tree $3, \mathrm{D}_{1}=$ Diseased tree $1, \mathrm{D}_{2}=$ Diseased tree $2,+\mathrm{ve}=$ positive control, $-\mathrm{ve}=$ negative control (DMSO), Inhibition zones expressed as mean \pm standard deviation and $-=$ no zone of inhibition.

Minimum Inhibitory Concentration (MIC) The Minimum Inhibitory Concentrations (MICs) of the crude extracts of the endophytic fungi isolated from healthy cashew trees against pathogen of medical importance are presented in Table 3. The concentrations are presented as mean \pm standard deviation. Aspergillus species portrayed the strongest activity against fungal pathogens with the strongest MIC value of $3.125 \mathrm{mg} / \mathrm{ml}$, followed by Neopestalotiopsis and Penicillium species both portraying strong antimicrobial activity against the tested bacteria with MIC value of $6.25 \mathrm{mg} / \mathrm{ml}$, while Daldinia species portrayed the weakest antimicrobial activity against the bacteria with MIC value of $12.5 \mathrm{mg} / \mathrm{ml}$.

Table 3: Minimum inhibitory concentrations $(\mathrm{mg} / \mathrm{mL})$ of the crude extracts of endophytic fungi isolated from disease and resistant cashew trees against pathogens of medical importance.

\begin{tabular}{|c|c|c|c|c|}
\hline \multirow[t]{2}{*}{ Source } & \multirow[t]{2}{*}{ Endophytes } & \multicolumn{3}{|l|}{ Tested pathogen } \\
\hline & & Staphylococcus aureus & Escherichia coli & Candida tropicalis \\
\hline $\mathrm{R}_{1}$ Leaves & Neopestalotiopsis & 50 & 6.25 & 6.25 \\
\hline $\mathrm{R}_{2}$ Leaves & Penicillium & 6.25 & 50 & 25 \\
\hline $\mathrm{R}_{1}$ Roots & Lasidioplodia & 100 & 50 & 3.125 \\
\hline $\mathrm{R}_{3}$ Leaves & Daldinia & 100 & 12.5 & 6.25 \\
\hline $\mathrm{D}_{1}$ Leaves & Aspergillus & 50 & 100 & 3.125 \\
\hline
\end{tabular}

Note: $\mathrm{R}_{1}=$ Resistant tree $1, \mathrm{R}_{2}=$ Resistant tree $2, \mathrm{R}_{3}=$ Resistant tree $3, \mathrm{D}_{1}=$ Diseased tree 1 . Concentration presented as mean \pm standard deviation.

\section{Discussion}

This paper is the first report on isolation of endophytic fungi from diseased and resistant cashew trees intended to isolate endophytes and test their antimicrobial activities against Fusarium oxysporum causing cashew wilt disease and pathogens of medical importance namely S. aureus, E. coli and C. tropicalis. Eight (8) endophytic fungal species were isolated, of which four (4) isolates were from diseased plants and four (4) isolates were from resistant plants. The isolates were confirmed to belong to the eight genera using the ITS molecular mark which delineated closely 
related taxa. The isolates were well supported to belong to the eight genera compared to the already described sequences with support values of $\mathrm{PP} \geq 0.95$ and MLbs $\geq 70 \%$ (Figure 4). Those isolates from resistant plants are Daldinia sp, Neopestalotiopsis sp, Penicillium $\mathrm{sp}$, and Lasidioplodia $\mathrm{sp}$ and those from diseased plants are Auxarthron sp, Aspergillus sp, Aspergillus sp, and Lasidioplodia sp. The species composition differed between resistant and diseased cashew tree except for one species Lasidioplodia sp which appeared in both resistant and diseased cashew trees. The nonspecificity of endophytes has been also shown in other studies. For example, Huang et al. (2008) established that some endophytes are host specific which means that they only restricted to single host, thus not occurring in different plants in the same habitat, while others are host recurrence whereby they predominantly occur on a specific host or can be occurring in infrequently on other host plant in the same habitat. All fungal endophytes from resistant trees and only one endophytic fungus Aspergillus sp from diseased plants had antimicrobial activities against the tested bacteria and fungus Candida tropicalis. Neopestalotiopsis sp showed strong antimicrobial activities against all the tested pathogens and this was also reported by Tanapichatsakul et al. (2019) as they did production of eugenol from fungal endophytes Neopestalotiopsis sp. Lasiodiplodia sp were very active against the fungus Candida tropicalis. The findings are similar to those reported by Moron et al. (2018) in their studies on antimicrobial activities of crude culture extracts from mangrove fungal endophytes collected in Luzon Island, Philippines. Penicillium sp was active against tested bacteria and had activity against fungi, and this was also reported to produce a range of medicinally important metabolites including antimicrobials (Lucas et al. 2007) and antifungals (Nicoletti et al. 2007). Daldinia sp has got partially active antibacterial activities since this plant was reported to possess many therapeutic properties like antimicrobial, cytotoxicity and anti-inflammatory activities (Shylaja et al. 2018). Only one endophytic fungus Aspergillus sp from diseased plants showed activities against all the tested microbes.

All endophytic fungal isolates revealed no activity against Fusarium oxysporum that causes cashew wilt disease. This implies that endophytes harbored in these resistant plants could not be the ones influencing resistance against pathogenic Fusarium. Possibly there might be other factors that contribute to their resistance to cashew wilt diseases. Some literature denotes that mineral contents like zinc, potassium, iron, manganese, calcium and silicon mineral elements contribute to plants protection against pathogens (Orr and Nelson 2018). Other known factors such as availability of organic matter that influence the chemical, physical and biological characteristics of soil, and endophytic bacteria (da Costa Ribeiro Lins et al. 2014) have also been reported to cause disease suppression.

\section{Conclusion}

From this study, eight endophytes were isolated from cashew trees and based on phylogenetic analysis, the isolates from resistant plants were grouped together with species of Neopestalotiopsis, Penicillium, Lasidioplodia and Daldinia and those from infected trees were grouped with species of Auxarthron and Aspergillus. Differences in species composition were observed between the infected trees and resistant ones. The isolated endophytic fungal crude extracts had antimicrobial activities against selected human pathogenic bacteria and fungi. This could contribute to the discovery and innovation of therapeutics and products of pharmacological importance. The isolated endophytic fungal crude extracts had no antimicrobial activities against Fusarium oxysporum. More research work should be conducted to elucidate factors that could contribute to resistance of cashew plants to Fusarium oxysporum. The scope of the studied area could be increased to other infected areas beyond Mtwara cashew 
plantations including coastal areas with similar cashew wilting disaster.

\section{Acknowledgment}

The authors send their heartfelt gratitude and thanks to the Department of Molecular Biology and Biotechnology, Chemistry Department, Botany Department, TARI-Naliendele-Cashew Research Programme and other people who provided assistance in this research.

\section{References}

Abdollahzadeh J, Javadi A, Mohammadi GE, Zare R and Phillips AJ 2010 Phylogeny and morphology of four new species of Lasiodiplodia from Iran. Persoonia 25: 1-10.

Bhalodia NR and Shukla VJ 2011 Antibacterial and antifungal activities from leaf extracts of Cassia fistula I: An ethnomedicinal plant. J. $A d v$. Pharmaceut. Technol. Res. 2(2): 104-109.

Campos FF, Sales Junior PA, Romanha AJ, Araújo MS, Siqueira EP, Resende JM, Alves T, Martins-Filho OA, Santos VL, Rosa CA and Zani CL 2015 Bioactive endophytic fungi isolated from Caesalpinia echinata Lam (Brazilwood) and identification of beauvericin as a trypanocidal metabolite from Fusarium $s p$. Memórias Instituto Oswaldo Cruz 110: 65-74.

Dharajiya D, Pagi N, Jasani H and Patel P 2017 Antimicrobial activity and phytochemical screening of aloevera. Int. J. Curr. Microbiol. Appl. Sci. 6(3): 2152-2162.

Dou ZP, He W and Zhang Y 2017 Lasiodiplodia chinensis, a new holomorphic species from China. Mycosphere 8(2): 521-532.

da Costa Ribeiro Lins M, Fontes J, Vasconcelos N, Santos D, Ferreira O, Azevedo J, Araújo J and Lima G 2014 Plant growth promoting potential of endophytic bacteria isolated from cashew leaves. Afr. J. Biotechnol. 13: 3360-3365.

Hillis DM and Bull JJ 1993 An empirical test of bootstrapping as a method for assessing confidence in phylogenetic analysis. Syst Biol. 42(2): 182-192.

Jahiri X 2013 Isolation of fungal endophytes from grasses by laser micro dissection and pressure catapulting. Master thesis The Artic University Norway.

Laich F and Andrade J 2016 Penicillium pedernalense sp. nov isolated from white leg shrimp heads waste compost. Int. J. Syst. Evol. Microbiol. 66(11): 4382-4388.
Lucas EM, Castro MC and Takahashi JA 2007 Antimicrobial properties of sclerotiorin, isochromophilone VI and pencolide metabolites from a Brazilian cerrado isolate of Penicillium sclerotiorum. Van Beyma. Brazi. J. Microbiol. 38: 785-789

Machado AR, Pinho DB, and Pereira OL 2014 Phylogeny, identification and pathogenicity of the Botryosphaeriaceae associated with collar and root rot of the biofuel plant Jatropha curcas in Brazil, with a description of new species of Lasiodiplodia. Fungal Divers 67(1): 231-247.

Maharachchikumbura SS, Hyde KD, Groenewald JZ, Xu J and Crous PW 2014 Pestalotiopsis revisited. Stud. Mycol. 79: 121-186.

Marques MW, Lima NB, de Morais MA, Barbosa MA, Souza BO, Michereff SJ, Phillips A and Camara MP 2013 Species of Lasiodiplodia associated with mango in Brazil. Fungal Divers. 61(1): 181-193

Masumi S, Mirzaei S, Zafari D and Kalvandi R 2015 Isolation, identification and biodiversity of endophytic fungi of Thymus. Progr. Biol. Sci. 5(1): 43-50

Mbasa WV, Nene WA, Kapinga FA, Lilai SA and Tibuhwa DD 2021 Characterization and chemical management of cashew Fusarium wilt disease caused by Fusarium oxysporum in Tanzania. Crop Protection 139: 105379.

Moron L, Lim Y and Dela Cruz T 2018 Antimicrobial activities of crude culture extracts from mangrove fungal endophytes collected in Luzon Island, Philippines. Philipp. Sci. Lett. 11: 28-36.

Mwanga Z, Mvungi E and Tibuhwa D 2019 Antimicrobial activities of endophytic fungi secondary metabolites from Moringa oleifera (Lam). Tanz. J. Sci. 45(3): 463-476.

Nicoletti R., Lopez-Gresa MP, Manzo E, Carella A and Ciavatta ML 2007 Production and fungitoxic activity of Sch 642305 a secondary metabolite of Penicillium canescens. Mycopathologia 163: 295-301.

Norphanphoun C, Jayawardena RJ, Chen Y, Wen TC and Hyde KD 2019 Morphological and phylogenetic characterization of novel pestalotioid species associated with mangroves in Thailand. Mycosphere 10(1): 531-578.

Nylander JAA 2004 MrModeltest v2. Program distributed by the author. Evolutionary Biology Centre, Uppsala University. 
Orr R and Nelson PN 2018 Impacts of soil abiotic attributes on Fusarium wilt, focusing on bananas. Appl. Soil Ecol. 132: 20-33.

Parenicova L, Skouboe P, Frisvad JC, Samson RA, Rossen L, Hoor-Suykerbuyk M and Visser J 2015 Combined molecular and biochemical approach identifies Aspergillus japonicus and Aspergillus aculeatus as two species. National Center for Biotechnology Information, NIH, Bethesda, MD 20894, USA.

Perrone G, Varga J, Susca A, Frisvad JC, Stea G, Kocsube S, Toth B, Kozakiewicz Z and Samson RA 2008 Aspergillus uvarum sp. Nov, an uniseriate black Aspergillus species isolated from grapes in Europe. Int. J. Syst. Evol. Microbiol. 58(4): 1032-1039.

Peterson SW 2008 Phylogenetic analysis of Aspergillus species using DNA sequences from four loci. Mycologia 100 (2): 205-226.

Quinto E and Santos M 2005 A guidebook plant screening: phytochemical and biological. Guevara $B Q$ ed. University of Santo Tomas Publishing House, Manila.

Ramesh V, Arivudainambi USE, Rajendran A 2017 The molecular phylogeny and taxonomy of endophytic fungal species from the leaves of Vitex negundo. Studies in Fungi 2(1): 26-38.

Ronquist F and Huelsenbeck JP 2003 MrBayes 3: Bayesian phylo- genetic inference under mixed models. Bioinformatics 19(12): 1572-1574.

Ronoh RC, Budambula NLM, Mwirichia RK and Boga HI 2013 Isolation and characterization of actinobacteria from Lake Magadi, Kenya. Afr. $J$. Microbiol. Res. 7: 4200-4206.

Schoch CL, Robbertse B, Robert V, Vu D, Cardinali G, Irinyi L, Meyer W, Nilsson RH, Hughes K, Miller AN and Kirk PM 2014 Finding needles in haystacks, linking scientific names, reference specimens and molecular data for Fungi. Database (Oxford).

Schulz B, Wanke U, Draeger S and Aust H 1993 Endophytes from herbaceous plants and shrubs: effectiveness of surface sterilization methods. Mycological Res. 97(12): 1447-1450.

Shylaja G, Sasikumar K and Satiavelu A 2018 Antimycobacterial potential of resorcinol type lipid isolated from Chaetomium cupreum, an endophytic fungus from Mussaenda luteola. Bangladesh J. Pharmacol. 13: 114-119.

Sridhar KR and Raviraja NS 1995 Endophytes a crucial issue. Current. Sci. 69(7): 570-574.
Stadler M, Laessoe T, Fournier J, Decock C, Schmieschek B, Tichy HV and Persoh D 2014 A polyphasic taxonomy of Daldinia (Xylariaceae). Stud. Mycol. 77: 1-143.

Stamatakis A 2014 RAxML version 8, a tool for phylogenetic analysis and post-analysis of large phylogenies. Bioinformatics 30(9): 1312-1313.

Tanapichatsakul C, Khruengsai S, Monggoot S and Pripdeevech P 2019 Production of eugenol from fungal endophytes Neopestalotiopsis sp. and Diaporthe $s p$. isolated from Cinnamomum loureiroi leaves. PeerJ 7: e6427.

Tibuhwa DD and Shomari S 2016 Fusarium wilt disease: An emerging threat to cashew nut crop production in Tanzania. Asian J. Plant Pathol. 10: $36-48$.

Umesha S, Manukumar HM and Raghava S 2016 A rapid method for isolation of genomic DNA from food-borne fungal pathogens. 3 Biotech 6 : 123.

U'Ren JM, Miadlikowska J, Zimmerman NB, Lutzoni F, Stajich JE and Arnold AE 2016 Contributions of North American endophytes to the phylogeny, ecology and taxonomy of Xylariaceae (Sordariomycetes, Ascomycota). Mol. Phylogenet. Evol. 98: 210-232.

Verma VC, Kharwar RN and Strobel GA 2009 Chemical and functional diversity of natural products from plant-associated endophytic fungi. Nat. Prod. Commun. 4(11): 1511-1532.

Visagie CM, Renaud JB, Burgess KM, Malloch DW, Clark D, Ketch L, Urb M, Louis-Seize G, Assabgui R, Sumarah MW and Seifert KA 2016 Fifteen new species of Penicillium. Persoonia 36: 247-280.

Vu D, Groenewald M, de Vries M, Gehrmann T, Stielow B, Eberhardt U, Al-Hatmi A, Groenewald JZ, Cardinali G, Houbraken J, Boekhout T, Crous PW, Robert V and Verkley GJ 2019 Large scale generation and analysis of filamentous fungal DNA barcodes boosts coverage for kingdom fungi and reveals thresholds for fungal species and higher taxon delimitation. Stud. Mycol. 92: 135-154.

Yang T, Groenewald JZ, Cheewangkoon R, Jami F, Abdollahzadeh J, Lombard L and Crous PW 2017 Families, genera, and species of Botryosphaeriales. Fungal Biol. 121: 322-346. 